\title{
Phase Transformations in Fly Ash-Based Solids
}

\author{
Ivana Perná *(i), Tomáš Hanzlíček, Monika Šupová and Martina Novotná \\ Institute of Rock Structure and Mechanics, The Czech Academy of Sciences, 18209 Prague, Czech Republic; \\ hanzlicek@irsm.cas.cz (T.H.); supova@irsm.cas.cz (M.Š.); novotna@irsm.cas.cz (M.N.) \\ * Correspondence: perna@irsm.cas.cz; Tel.: +420-266-009-253; Fax: +420-284-680-105
}

Received: 27 July 2020; Accepted: 10 September 2020; Published: 11 September 2020

\begin{abstract}
The presented article describes the phase transformations in solid bodies based on fluid fly ash (FFA) over eight years from the initial to the final phases. FFA has been selected as a type of industrial waste whose amount has been growing in recent years. This type of ash has self-hardening properties when watered because of the conditions of its origin. The specific temperature of fluid burning and the addition of calcium carbonate into the burning zone create a mixture of phases which are, even when solidified, ready to form new crystal phases, especially alumina-silicates, relicts of coal clay minerals. For experiments, bricks from the mixture of FFA and quartz sand were industrially produced and left outside. Subsequent mineralogical analyses of samples of various ages confirmed differences in phase compositions. It is supposed that the main role in the presented changes is played by the content of the roentgen-amorphous part of alumina-silicates because they are likely to be transformed into a stable form of feldspar. In addition to that, this article presents the hypothesis of a moving agent, which could explain the transformations in the final bodies.
\end{abstract}

Keywords: fluid fly ash; solidification; phase transformation; crystal phases; roentgen-amorphous phase; alumina-silicates; feldspars

\section{Introduction}

Global energy consumption is still rising. Although also various other sources are used, including solar, wind, and nuclear energy, the majority of energy and heat in many countries is obtained from coal combustion [1-3].

The main problem of coal burning is that it is a permanent source of $\mathrm{CO}_{2}$ and $\mathrm{NO}_{\mathrm{x}}$ gases, which are contaminating the atmosphere $[4,5]$. The second problem, which is serious as well, is represented by the waste materials created (e.g., ashes and slag). Many power stations use classic boilers with a high temperature of coal burning, where all alumina-silicates in ashes and slag are transformed into high-temperature structures as spinels and mullites [6,7]. Sulfur gases are generally captured by wet-washing in calcium carbonate milk [8].

An alternative and more ecological coal burning method is fluidized bed combustion, where crushed coal is burned in a fluid layer together with calcium carbonate $\left(\mathrm{CaCO}_{3}\right)$ [9]. The burning temperature of $820{ }^{\circ} \mathrm{C}$ ensures the formation of lime $(\mathrm{CaO})$, resulting from calcium carbonate decomposition. Simultaneously, extremely active lime captures all $\mathrm{SO}_{\mathrm{x}}$ originating from the coal $[10,11]$.

The solid waste materials originating during fluid combustion are fluidized bed ash (FBA) and fluid fly ash (FFA). FBA mainly consists of anhydrite $\left(\mathrm{CaSO}_{4}\right)$, quartz $\left(\mathrm{SiO}_{2}\right)$, lime $(\mathrm{CaO})$ and/or portlandite $\left(\mathrm{Ca}(\mathrm{OH})_{2}\right)$, and very often contains remaining non-decomposed calcite $\left(\mathrm{CaCO}_{3}\right)[12,13]$. The composition of FFA is similar, complemented by roentgen-amorphous phases [14,15]. These types of ash are subdivided into two types, class $\mathrm{C}$ and class $\mathrm{F}$, according to the content of free lime (10-35 wt.\% and less than $5 \mathrm{wt} . \%$, respectively), which depend on the type of coal burned [16]. Due to the high content of free lime, the application of class $C$ fly ash is limited to the cement industry $[16,17]$. 
Considering the temperature of coal burning, which does not exceed $820^{\circ} \mathrm{C}$, and the technology of the revolve-ring coal particles in the fluid layer, the following estimation could be made: Aluminum ion under these conditions changes its coordination to the oxygen and forms a five-/four-fold coordinated ion. The silicon ion from the original lattice does not change its coordination. This arrangement of the four-fold coordinated silicon bound to the five-/four-fold coordinated aluminum is known as the precursor of a new structure [18-21].

Fluid fly ash (FFA) is a specific kind of waste with the following properties:

- a high content of dehydrated alumina-silicates, the residue of clayed substances [22,23];

- a specific position of aluminum ions, caused by the low temperature of burning [15];

- a rather high number of compounds formed by the reaction of calcium oxide with sulfur [14];

- a content of extremely reactive free calcium oxide [24].

A previous study [12] presenting new crystallized phases and alumina-silicate in the specific form in fluid ashes has confirmed the content of calcium in anhydrite $\left(\mathrm{CaSO}_{4}\right)$, lime $(\mathrm{CaO})$ and portlandite $\left(\mathrm{Ca}(\mathrm{OH})_{2}\right)$ by the X-ray diffraction $(\mathrm{XRD})$ analyses of ashes. The content of alumina and silica in FFA identified by $\mathrm{X}$-ray fluorescence (XRF) analysis represents an inorganic constituent of coal, which is generally a residue of clayed substances, including micas. XRD also corroborates the amorphous part, which could be explained as a reflection of a dehydrated clay lattice. The increased quantity of the inorganic constituents containing calcium ions results in solid materials when watered.

Another study focused on the behavior of fly ash during thermal exposure [15]. Specific phase changes were revealed in fluid fly ashes thermally treated at different temperatures. New final and stable phases, gehlenite and anorthite, were identified by XRD analysis, and the corresponding bonds were confirmed by infrared spectroscopy measurements.

In addition to those already mentioned, both studies scrutinized the particular positions of clayed residues where the five-/four-fold aluminum-coordinated ions joined together with silicon ions are formally prepared to create a chained structure or structures forming feldspathoids. In these, all aluminum ions are at a four-fold position to the oxygen, and their negative charges are balanced by alkali ions.

However, all described results have been obtained under laboratory conditions. For this reason, bricks have been industrially produced from a mixture of fluid ash and sand by vibro-pressing. They were then used to build a wall in an outdoor environment. After two and eight years, samples were taken and further analyzed. The main task was to identify the crystalline phases related to the phase differences of the fresh solid and solids after two and eight years of exposure to outdoor conditions. Up to now, these phase transformations have never been observed or described at normal temperatures and pressures, only under hydrothermal conditions [25].

\section{Experimental Part}

\subsection{Materials}

The C-type fluid fly ash (FFA) supplied by the ALPIQ power station, Kladno (Central Bohemia, Czech Republic), was a product of fluid-burning technology (at a temperature of $820^{\circ} \mathrm{C}$ ) using coal from East-North Moravia (Ostrava coal basin, Czech Republic). The chemical and mineralogical compositions are presented in Section 3. Result and Discussion.

The construction sand PR 504 with a grain-size range of 0.1-4.0 $\mathrm{mm}$ used in the experiments was industrially supplied by the company Provodínské písky a.s. (Provodín, Czech Republic), which guarantees its parameters.

\subsection{Sample Preparation}

The studied samples came from industrially prepared bricks made from a mixture of fluid fly ash, quartz sand and water (the ratio 4.6:4.5:0.9, respectively). The fly ash was not treated 
for the preparation of bricks and was used as supplied by the power station. The technology of vibro-compaction requires three fractions of sand aggregates to a total weight of $45 \%$ of the total brick weight. The humidity of the vibro-compaction mass was 8.8-9.2 wt.\%. Fabricated bricks with the dimensions of $250 \mathrm{~mm} \times 125 \mathrm{~mm} \times 75 \mathrm{~mm}$ were left covered by plastic sheets at an ambient temperature for 14 days. The studied bricks were used for the construction of a small wall in the open air and left there (Buštěhrad, Czech Republic, GPS: 50.1584733 N, 14.1675169 E).

In 2012, test specimens of solidified fluid fly ash (a simple mixture of ash and water without aggregates) were manufactured in the laboratory to specify two-year results from outdoor samples. These laboratory specimens, with dimensions of $40 \mathrm{~mm} \times 40 \mathrm{~mm} \times 160 \mathrm{~mm}$, were used for mechanical-property measurements, and the fragments were submerged in water in a plastic box and covered by a lid. The next tests were performed in 2020 .

\subsection{Methods}

For analyses, the obtained samples of ashes were treated in a laboratory dryer up to constant weight then pulverized by a Retsch friction mill reaching a particle size of $0-0.2 \mathrm{~mm}$. The ground ash was stored in containers without access to air.

The chemical analyses were performed by an X-ray fluorescence (XRF) analyzer Spectro IQ (Kleve, Germany) with the palladium target material and a target angle from the central ray of $90^{\circ}$. The focal point was a $1 \mathrm{~mm} \times 1 \mathrm{~mm}$, with a maximum anode dissipation of 50 watts and $10 \mathrm{cfm}$ forced-air cooling. The instrument was equipped with a HOPG Barkla crystal and measured at an energy range of 50.0 and $25.0 \mathrm{keV}$ under an atmosphere of helium. The tested samples were prepared using the pressed-pellet method: $4.0 \mathrm{~g}$ of the material (a particle size of $15-20 \mu \mathrm{m}$ ) was mixed for $10 \mathrm{~min}$ with $0.9 \mathrm{~g}$ of a binding additive (HWC Hoechst wax, Germany). The pressing power was $80 \mathrm{kN}$. The measurements were performed at $23{ }^{\circ} \mathrm{C}$, at atmospheric pressure and humidity below $30 \%$. Polypropylene $4-\mu \mathrm{m}$ protective film was used. The detection limit of the method ranges from 0.3 to $12(2 \times 300 \mathrm{~s})$ depending on the elements and matrix of the sample.

X-ray diffraction records were taken for the X-ray diffractometer Bruker D8 (Karlsruhe, Germany) Advance using a $\mathrm{CuK} \alpha$ radiation and position-sensitive semiconductor detector Lynx Exe XE (Karlsruhe, Germany). The recordings were performed with an automatic divergence aperture (ADS, $10 \mathrm{~mm}$ ) in the range of $4-80^{\circ}$, with a step of $0.015^{\circ}$ and a 0.8 -seconds reading time per step. An internal standard (15 wt.\% of $\mathrm{ZnO}$ ) was added to the sample to estimate the amorphous component. The records were qualitatively evaluated using Diffrac EVA 2015 software (Bruker AXS, 2015, Karlsruhe, Germany), HighScore 3.0 (PANalytical 2011) and a PDF-2-2002 database. Subsequent semiquantitative phase analysis was performed using the Rietveld method in the Topas 5 program (Bruker AXS, 2015, Germany). The supplied ground samples were further ground to the required fineness by grinding in a McCrone mill ( $\mathrm{ZrO}_{2}$ grinding elements, grinding for $7 \mathrm{~min}$ in suspension with ethanol). Samples for $\mathrm{X}$-ray diffraction were prepared by the so-called side-loading method. The detection limit of this method ranges from about 0.2 to $0.5 \mathrm{wt} . \%$ depending on the nature (crystallinity) of the phases present. The contents of the phases are defined as follows: major (over $15 \mathrm{wt} . \%$ ), minor (approx. 5-15 wt.\%) and trace (below $5 \mathrm{wt} . \%$ ).

Solid-state nuclear magnetic resonance (ss-NMR) spectra were measured at $11.7 \mathrm{~T}$ using a Bruker Avance III HD 500 US/WB NMR spectrometer (Karlsruhe, Germany, 2013) in a double-resonance 4-mm probe-head at spinning frequencies $\omega_{\mathrm{r}} / 2 \pi=11 \mathrm{kHz}$. The ${ }^{27} \mathrm{Al}$ and ${ }^{29} \mathrm{Si}$ MAS NMR spectra were recorded using the single-pulse technique. The applied nutation frequency of the $B_{1}$ field for excitation was $\omega_{1} / 2 \pi$ $=89.3 \mathrm{kHz}$. The duration of the ${ }^{29} \mathrm{Si}$ excitation pulse was $4 \mu \mathrm{s}$, while the duration of the ${ }^{27} \mathrm{Al}$ excitation pulse was shortened to $0.5 \mu \mathrm{s}$. The number of scans accumulated by the spectra with an acceptable signal-to-noise ratio was 1024-4096. During data acquisition, the high-power dipolar decoupling SPINAL-64 was applied. The applied nutation frequency of the $B_{1}\left({ }^{1} \mathrm{H}\right)$ field for the high-power dipolar decoupling was $\omega_{1} / 2 \pi=89.3 \mathrm{kHz}$. The repletion delay between consecutive scans was 10 and $1 \mathrm{~s}$ for ${ }^{29} \mathrm{Si}$ and ${ }^{27} \mathrm{Al}$ MAS NMR experiments, respectively. The ${ }^{27} \mathrm{Al}$ chemical-shift scale was calibrated 
with $\mathrm{Al}\left(\mathrm{NO}_{3}\right)_{3}(0.0 \mathrm{ppm})$, and the ${ }^{29} \mathrm{Si}$ chemical-shift scale was calibrated using $\mathrm{M}_{8} \mathrm{Q}_{8}$ as an external standard (-108.9 ppm). Dried, finely powdered sample was placed into the 4-mm thin-wall $\mathrm{ZrO}_{2}$ rotor in a glovebox and subsequently stored at room temperature in inert atmosphere. To compensate for frictional heating of the spinning samples, all NMR experiments were measured under active cooling. The sample temperature was maintained at $298 \mathrm{~K}$. The detection limit of the experimental method used ranges from about 0.5 to $5.0 \mathrm{wt} . \%$ depending on the nature (crystallinity) of the phase present. For highly crystalline substances, the detection limit is approximately $0.5-1.0 \mathrm{wt} . \%$; for amorphous substances it reaches approximately $2.0-5.0 \mathrm{wt} . \%$. The NMR spectrometer was completely calibrated and all experimental parameters were carefully optimized prior to the investigation. The magic angle was set using a $\mathrm{KBr}$ sample during a standard optimization procedure, and homogeneity of the magnetic field was optimized using an adamantane sample (the resulting line-width at half-height $\Delta v 1 / 2$ was less than $3.5 \mathrm{~Hz}$ at $250 \mathrm{~ms}$ of acquisition time).

The Fourier transform infrared (FTIR) spectra were measured using a iS50 (Thermo Nicolet Instruments Co., Madison, WI, USA) spectrometer by the attenuated total reflection (ATR) method. Measurements were performed at $23{ }^{\circ} \mathrm{C}$, at atmospheric pressure and humidity below $30 \%$. Powdered samples were dried at $105^{\circ} \mathrm{C}$ to decrease the moisture content. Bands of water in the infrared spectrum, indicating the presence of moisture, can complicate the interpretation of the spectrum. Approximately $0.1 \mathrm{~g}$ of the dried powder sample was placed on the surface of the diamond crystal and compressed with a thrust screw. The area of scanned spot on the diamond crystal was $7 \mathrm{~mm}^{2}$. Infrared radiation was then emitted into the sample, averaging 64 scans with a resolution of $4 \mathrm{~cm}^{-1}$ in the middle infrared range of $4000-400 \mathrm{~cm}^{-1}$. The samples were measured 10 times to verify the homogeneity of the phase content in the individual parts of the sample. The penetration depth into the sample surface was in order units of $\mu \mathrm{m}$ (i.e., a characterization of very thin surface layers). However, due to the multiple reflections at the phase interface, a high quality spectrum could be obtained that was equivalent to the transmission spectrum measured at a sample thickness in the order of tens of $\mu \mathrm{m}$. Processing of obtained spectra were performed using the OMNIC Software 2019. Deconvolution procedures were performed with a Gaussian function. The starting calculation parameters for the curve fitting process (number of bands, band positions, width at half-maximum) were predetermined by the Fourier self-deconvolution. The detection limit for routine infrared analysis is $\sim 0.1 \mathrm{wt} . \%$.

\section{Results and Discussion}

The chemical analysis of FFA presented in Table 1 confirms the high content of $\mathrm{CaO}$ and $\mathrm{SO}_{3}$ related to the desulfurization method of fluid technology. The low value of the loss on ignition (L.O.I.) also corroborated the efficiency of this method of coal combustion. The identified alumina and silica (22.88 and $35.60 \mathrm{wt} . \%$, respectively) probably come from the clay residues contained in coal.

Table 1. The chemical compositions of the fluid fly ash (FFA) used in the experiments (wt.\%).

\begin{tabular}{cccccccccc}
\hline Materials/Oxides & $\mathrm{SiO}_{2}$ & $\mathrm{Al}_{2} \mathrm{O}_{3}$ & $\mathrm{Fe}_{2} \mathrm{O}_{3}$ & $\mathrm{TiO}_{2}$ & $\mathrm{CaO}$ & $\mathrm{MgO}$ & $\mathrm{K}_{2} \mathrm{O}$ & $\mathrm{SO}_{3}$ & L.O.I \\
\hline FFA & 35.60 & 22.88 & 6.97 & 1.69 & $20.63^{\mathrm{a}}$ & 1.20 & 0.74 & 6.86 & $2.66^{\mathrm{b}}$ \\
\hline
\end{tabular}

a The content of the free $\mathrm{CaO}$ (serving as an alkaline activator) is $10.65 \mathrm{wt} . \%{ }^{\mathrm{b}}$ The L.O.I. (loss on ignition) shows the loss of $\mathrm{CO}_{2}$ from calcite, with the unburned carbon content being below $0.2 \mathrm{wt} . \%$.

The mineralogical analysis (Table 2 and Figures S1 and S2) of fresh FFA corresponds to the chemical analysis (Table 1), and confirms the majority of anhydrite $\left(\mathrm{CaSO}_{4}\right)$ and lime $(\mathrm{CaO})$ and a minor content of calcite $\left(\mathrm{CaCO}_{3}\right)$ and quartz $\left(\mathrm{SiO}_{2}\right)$. In contrast, an analysis of the ash after two months shows the effect of carbonation and humidity. Lime partially reacted to calcite, which became the major phase, and partly reacted with anhydrite, creating an entirely new phase of ettringite $\left(\mathrm{Ca}_{6} \mathrm{Al}_{2}\left(\mathrm{SO}_{4}\right)_{3}(\mathrm{OH})_{12} \cdot 26\left(\mathrm{H}_{2} \mathrm{O}\right)\right)$. Both analyses also prove a roentgen-amorphous phase (approximately $43 \mathrm{wt} . \%)$ and hematite $\left(\mathrm{Fe}_{2} \mathrm{O}_{3}\right)$ in trace amounts. 
Table 2. XRD analyses of FFA.

\begin{tabular}{|c|c|c|}
\hline Samples/Phases & Fresh FFA & FFA after 2 Months \\
\hline Major phases & $\begin{array}{c}\text { anhydrite }\left(\mathrm{CaSO}_{4}\right), \\
\text { lime }(\mathrm{CaO})\end{array}$ & calcite $\left(\mathrm{CaCO}_{3}\right)$ \\
\hline Minor phases & $\begin{array}{l}\text { calcite }\left(\mathrm{CaCO}_{3}\right) \\
\text { quartz }\left(\mathrm{SiO}_{2}\right)\end{array}$ & $\begin{array}{c}\text { anhydrite }\left(\mathrm{CaSO}_{4}\right) \\
\text { quartz }\left(\mathrm{SiO}_{2}\right) \\
\text { ettringite } \\
\left(\mathrm{Ca}_{6} \mathrm{Al}_{2}\left(\mathrm{SO}_{4}\right)_{3}(\mathrm{OH})_{12} \cdot 26\left(\mathrm{H}_{2} \mathrm{O}\right)\right)\end{array}$ \\
\hline Traces & hematite $\left(\mathrm{Fe}_{2} \mathrm{O}_{3}\right)$ & hematite $\left(\mathrm{Fe}_{2} \mathrm{O}_{3}\right)$ \\
\hline Roentgen-amorphous phases & present & present \\
\hline
\end{tabular}

The ettringite even contained some aluminum ions, whose decisive amount is connected to silicon and represents the roentgen-amorphous part of the solid. Previous works $[12,26]$ have described a meta-stabile position of five-/four-fold coordinated aluminum ions surrounded by oxygen in a configuration with joined silicon. In these cases, the negative charge around the aluminum ion must be equilibrated by one positive charge, usually dotted by alkali. In cases of calcium abundance, there is also the possibility to balance two negative charges by one $\mathrm{Ca}^{2+}$ ion.

In order to identify the coordination of aluminum and silicon ions, the chemical and mineralogical analyses were complemented by ${ }^{27} \mathrm{Al}$ and ${ }^{29} \mathrm{Si}$ MAS-NMR (magic-angle spinning-nuclear magnetic resonance) analyses in the solid state, presented in Figures 1 and 2, respectively.

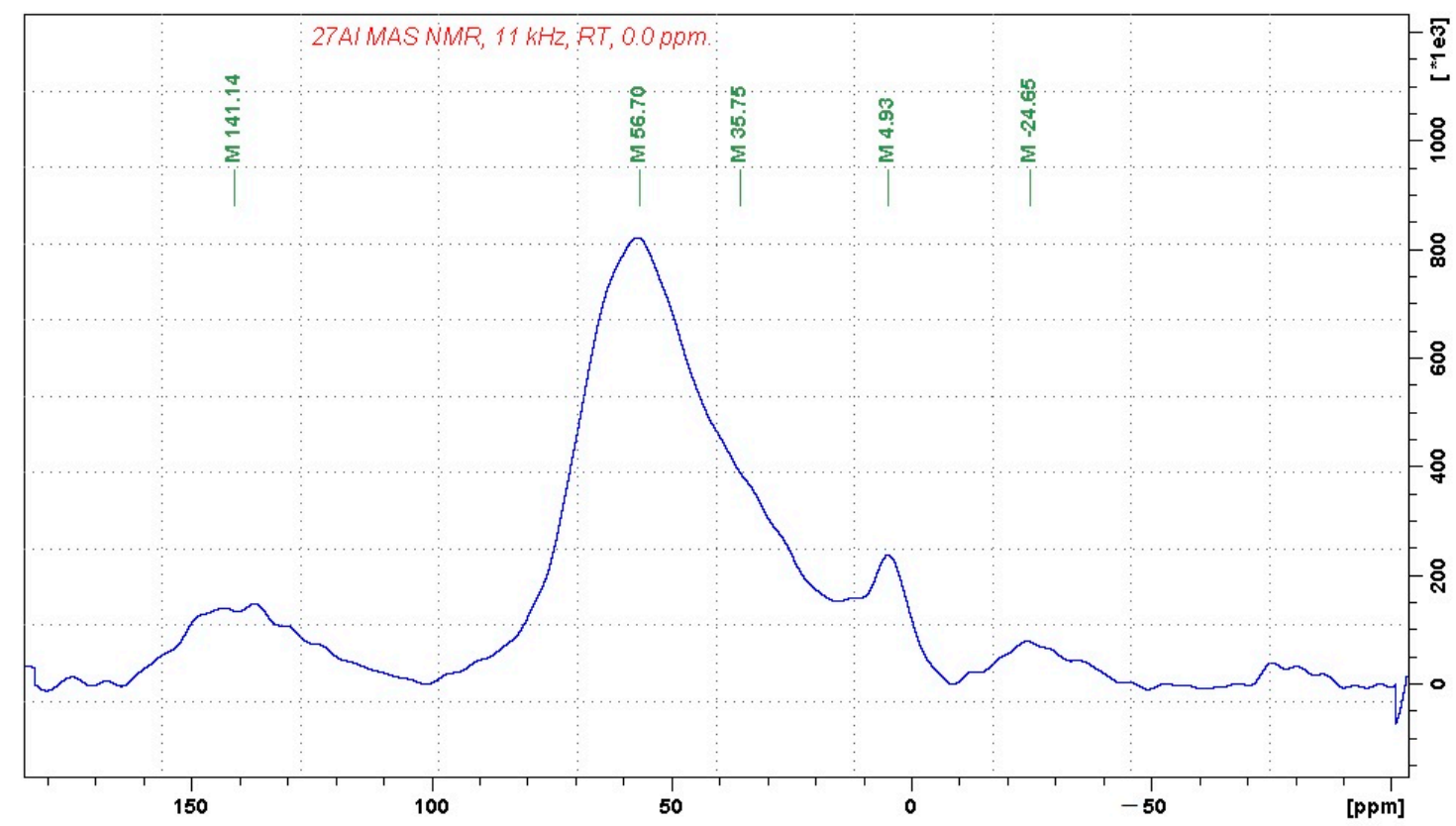

Figure 1. ${ }^{27} \mathrm{Al}$ MAS NMR spectroscopy of FFA.

The recorded ${ }^{27} \mathrm{Al}$ MAS NMR spectrum indicates that the investigated sample contains alumina-silicate bonds consisting predominantly of four-fold coordinated aluminum units (the signal at $56.7 \mathrm{ppm}$ ). The considerably weaker signal at $4.9 \mathrm{ppm}$ can be attributed to a small fraction of six-fold coordinated aluminum units, whereas the shoulder at approx. $35 \mathrm{ppm}$ may indicate the presence of five-fold coordinated aluminum building blocks. The signals at 141 and $-24 \mathrm{ppm}$ correspond to spinning sidebands. 


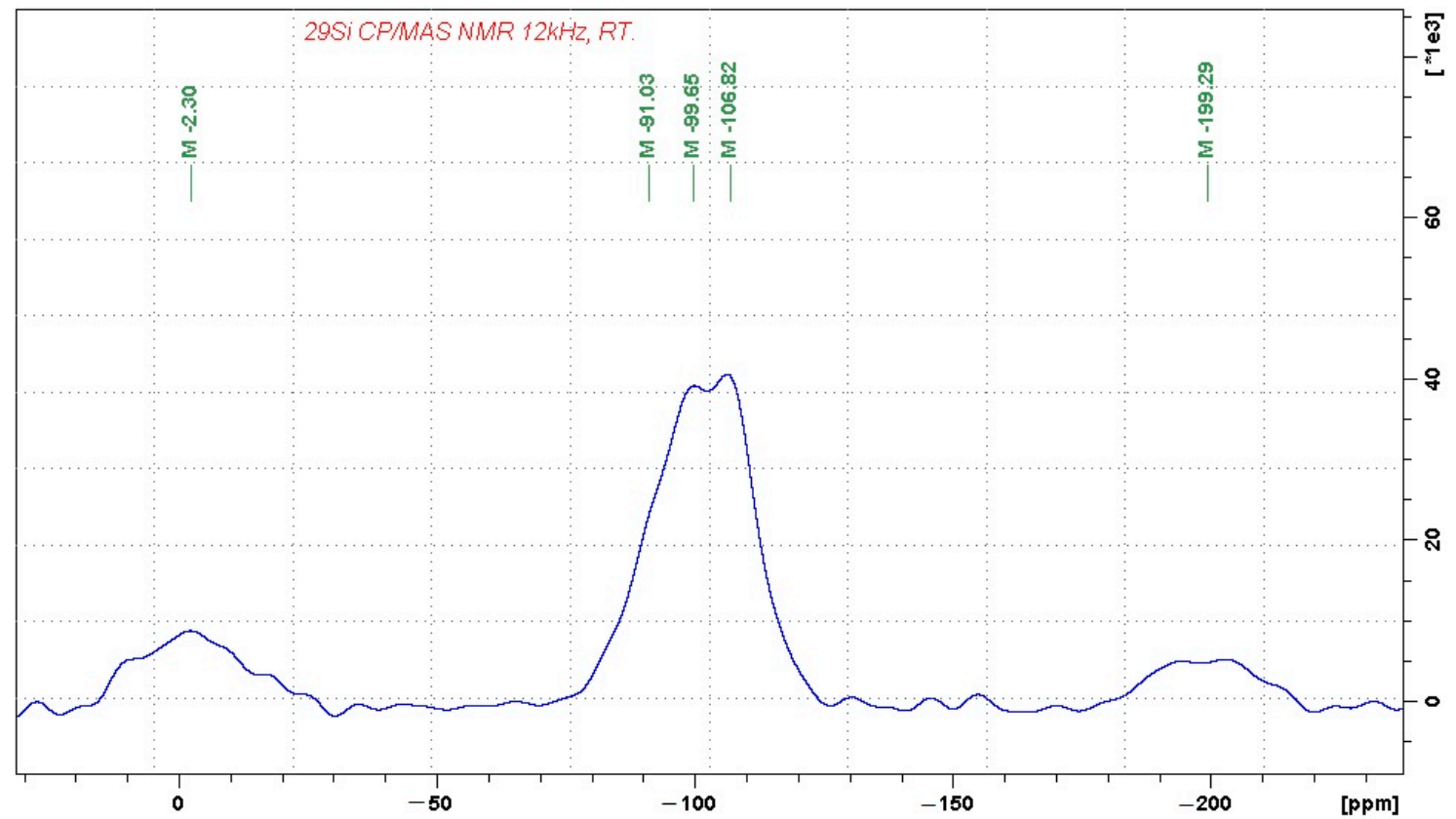

Figure 2. ${ }^{29}$ Si MAS NMR spectroscopy of FFA.

The ${ }^{29} \mathrm{Si}$ MAS NMR spectrum reflects the complex character of the alumina-silicate phase, which consists of $\mathrm{Q}^{4}(0 \mathrm{Al})$ units, probably representing amorphous $\mathrm{SiO}_{2}$ (the signal at $-107 \mathrm{ppm}$ ). The domains of $\mathrm{Q}^{4}(0 \mathrm{Al})$ are then accompanied by a broad distribution of other building units, which probably involve $\mathrm{Q}^{4}(1 \mathrm{Al})$ and $\mathrm{Q}^{4}(2 \mathrm{Al})$ building blocks, as reflected by the resonance frequencies at approximately -99 and $-91 \mathrm{ppm}$. The signals at -2 and $-200 \mathrm{ppm}$ again correspond to spinning sidebands. Their relatively high intensity indicates the presence of a considerable amount of paramagnetic species in the sample, such as $\mathrm{Fe}^{3+}$.

The performed analyses of the used fluid fly ash were complemented by an infrared analysis, which could explain in which phase alumina-silicates occur.

The FTIR spectrum of FFA (after two months) in the spectral region of $1500-500 \mathrm{~cm}^{-1}$ (Figure 3) has proven the presence of such phases as carbonates (the bands at 1405 and $874 \mathrm{~cm}^{-1}$ ), quartz (the bands at 799 and $778 \mathrm{~cm}^{-1}$ ) and anhydrite (the bands at 677,612 and $593 \mathrm{~cm}^{-1}$ ). The strongest absorption band, centered at $1098 \mathrm{~cm}^{-1}$, contains a series of overlapping bands belonging to sulfates (anhydrite and ettringite) and the $\mathrm{Si}-\mathrm{O}$ and $\mathrm{Si}-\mathrm{O}-\mathrm{Si}$ bonds of quartz, which are accompanied by less intense bands between 600 and $400 \mathrm{~cm}^{-1}$, respectively.

The deconvolution procedure of the spectral region of $1250-900 \mathrm{~cm}^{-1}$ (Figure 4) makes it possible to resolve these individual components. The bands at 1095, 1070 and $1031 \mathrm{~cm}^{-1}$ are related to the asymmetric stretching of Si-O-Si bonds. The weak band at $1200 \mathrm{~cm}^{-1}$ can be described as a spectral shoulder of the principal band at $1070 \mathrm{~cm}^{-1}$. Further bands (at 1160 and $1125 \mathrm{~cm}^{-1}$ ) are related to the asymmetric stretching of the sulfate ion $\left(v_{3} \mathrm{SO}_{4}\right)$. The band at $1125 \mathrm{~cm}^{-1}$ is indicative of the relative isolation of this ion in the hexagonal prism structure of ettringite [27]. Other bands, apparent at 990 and $936 \mathrm{~cm}^{-1}$, can be ascribed to the Si-O-Al bonds of amorphous non-specified aluminosilicates. 


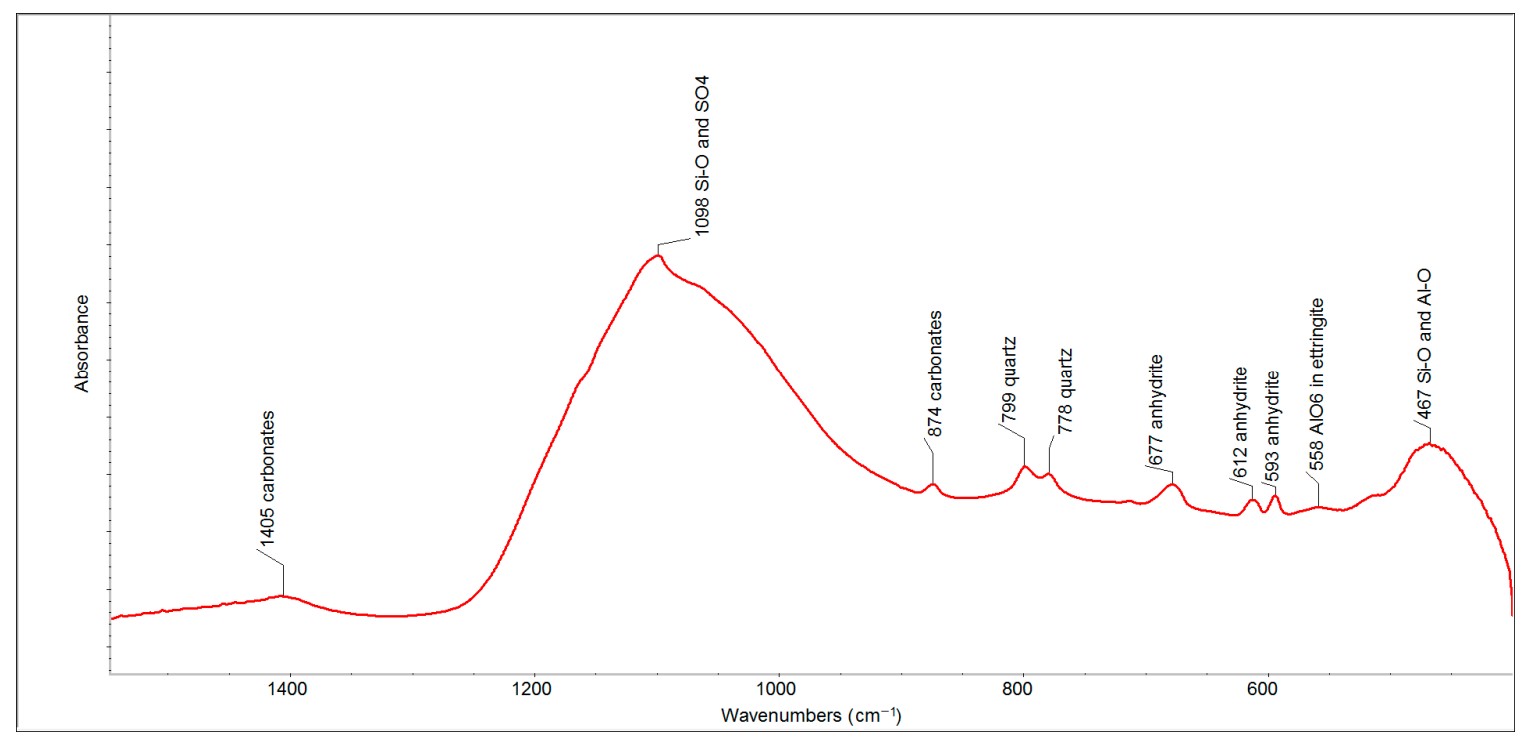

Figure 3. The FTIR spectrum of FFA (after two months).

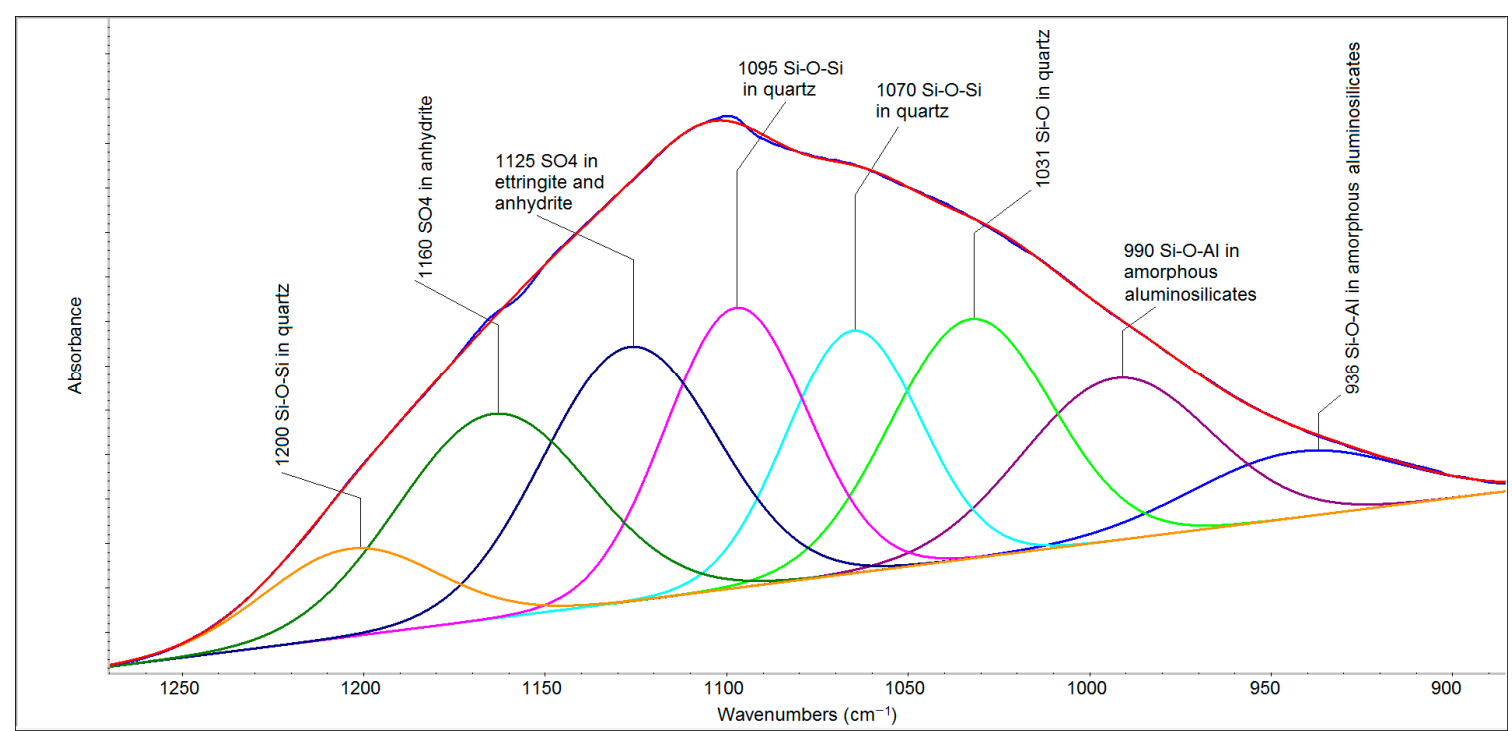

Figure 4. The deconvoluted spectral region of $1250-900 \mathrm{~cm}^{-1}$ of the FFA spectrum (after two months).

As already mentioned, the bricks produced were used to build a small wall. This wall was regularly inspected for any damage caused by external conditions, such as cracking or disintegration of the material. In order to identify changes in the fluid-fly-ash-based material, samples of fresh, two- and eight-year-old materials were taken and subsequently analyzed by XRF and XRD.

The chemical analyses, presented in Table 3, do not show significant differences between samples.

Table 3. The chemical composition of vibro-pressed samples (wt.\%).

\begin{tabular}{cccccccccc}
\hline Materials/Oxides & $\mathrm{SiO}_{2}$ & $\mathrm{Al}_{2} \mathbf{O}_{3}$ & $\mathrm{Fe}_{2} \mathrm{O}_{3}$ & $\mathrm{TiO}_{2}$ & $\mathrm{CaO}$ & $\mathbf{M g O}$ & $\mathbf{K}_{\mathbf{2}} \mathrm{O}$ & $\mathbf{S O}_{3}$ & L.O.I \\
\hline $\begin{array}{c}\text { Fresh solid } \\
\text { Outdoor sample }\end{array}$ & 57.55 & 8.54 & 2.85 & 0.53 & 15.65 & 0.67 & 1.58 & 3.62 & 8.37 \\
$\begin{array}{c}\text { after 2 years } \\
\text { Outdoor sample } \\
\text { after 8 years }\end{array}$ & 56.17 & 8.94 & 2.92 & 0.53 & 15.17 & 0.63 & 1.66 & 3.42 & 7.88 \\
\hline
\end{tabular}

Table 4 and Figures S3-S5 show the results of the mineralogical analyses of fresh solid and twoand eight-year-old outdoor samples. 
Table 4. The XRD analyses of solid samples of different ages.

\begin{tabular}{|c|c|c|c|}
\hline Samples/Phases & Fresh Solid & $\begin{array}{l}\text { Outdoor Sample } \\
\text { after } 2 \text { Years }\end{array}$ & $\begin{array}{l}\text { Outdoor Sample } \\
\text { after } 8 \text { Years }\end{array}$ \\
\hline Major phases & $\begin{array}{c}\text { gypsum }\left(\mathrm{CaSO}_{4} \cdot 2 \mathrm{H}_{2} \mathrm{O}\right) \text {, quartz } \\
\left(\mathrm{SiO}_{2}\right) \\
\text { calcite }\left(\mathrm{CaCO}_{3}\right) .\end{array}$ & $\begin{array}{c}\text { quartz }\left(\mathrm{SiO}_{2}\right) \\
\text { calcite }\left(\mathrm{CaCO}_{3}\right)\end{array}$ & quartz $\left(\mathrm{SiO}_{2}\right)$ \\
\hline Minor phases & $\begin{array}{c}\text { ettringite } \\
\left(\mathrm{Ca}_{6} \mathrm{Al}_{2}\left(\mathrm{SO}_{4}\right)_{3}(\mathrm{OH})_{12} \cdot 26\left(\mathrm{H}_{2} \mathrm{O}\right)\right), \\
\text { aragonite }\left(\mathrm{CaCO}_{3}\right) \\
\text { anatas }\left(\mathrm{TiO}_{2}\right)\end{array}$ & $\begin{array}{c}\text { bassanite }\left(\mathrm{CaSO}_{4} 0.5 \mathrm{H}_{2} \mathrm{O}\right) \\
\text { orthoclase }\left(\mathrm{KAlSi}_{3} \mathrm{O}_{8}\right) \\
\text { albite } \\
\left(\mathrm{Na}_{0.98} \mathrm{Ca}_{0.02}\right)\left(\mathrm{Al}_{1.02} \mathrm{Si}_{2.98} \mathrm{O}_{8}\right) \\
\text { hematite }\left(\mathrm{Fe}_{2} \mathrm{O}_{3}\right)\end{array}$ & $\begin{array}{c}\text { calcite }\left(\mathrm{CaCO}_{3}\right), \\
\text { orthoclase }\left(\mathrm{KAlSi}_{3} \mathrm{O}_{8}\right), \\
\text { albite } \\
\left(\mathrm{Na}_{0.98} \mathrm{Ca}_{0.02}\right)\left(\mathrm{Al}_{1.02} \mathrm{Si}_{2.98} \mathrm{O}_{8}\right)\end{array}$ \\
\hline Traces & - & $\begin{array}{c}\text { muscovite } \\
\left(\mathrm{KAl}_{2} \mathrm{Si}_{3} \mathrm{AlO}_{10}(\mathrm{OH})_{2}\right)\end{array}$ & $\begin{array}{c}\text { muscovite } \\
\left(\mathrm{KAl}_{2} \mathrm{Si}_{3} \mathrm{AlO}_{10}(\mathrm{OH})_{2}\right)\end{array}$ \\
\hline Roentgen-amorphous phases & present & limited amount & limited amount \\
\hline
\end{tabular}

The mineral phases identified in the XRD patterns are included in Table 4. The main constituents are gypsum $\left(\mathrm{CaSO}_{4} \cdot 2 \mathrm{H}_{2} \mathrm{O}\right)$, quartz $\left(\mathrm{SiO}_{2}\right)$ and calcite $\left(\mathrm{CaCO}_{3}\right)$. The minor phases are formed by aragonite $\left(\mathrm{CaCO}_{3}\right)$, ettringite $\left(\mathrm{Ca}_{6} \mathrm{Al}_{2}\left(\mathrm{SO}_{4}\right)_{3}(\mathrm{OH})_{12} \cdot 26\left(\mathrm{H}_{2} \mathrm{O}\right)\right)$ and anatase $\left(\mathrm{TiO}_{2}\right)$. Roentgen-amorphous phase were also identified.

In contrast, an analysis of the sample after two years in an outdoor environment showed the absence of ettringite, instead of which bassanite $\left(\mathrm{CaSO}_{4} \cdot 0.5 \mathrm{H}_{2} \mathrm{O}\right)$ appeared. In addition, two new phases, orthoclase $\left(\mathrm{KAlSi}_{3} \mathrm{O}_{8}\right)$ and albite $\left(\mathrm{Na}_{0.98} \mathrm{Ca}_{0.02}\right)\left(\mathrm{Al}_{1.02} \mathrm{Si}_{2.98} \mathrm{O}_{8}\right)$, were identified in minor amounts, and hematite $\left(\mathrm{Fe}_{2} \mathrm{O}_{3}\right)$ and muscovite $\left(\mathrm{KAl}_{2} \mathrm{Si}_{3} \mathrm{AlO}_{10}(\mathrm{OH})_{2}\right)$ were discovered in traces. On the other hand, gypsum and aragonite were no longer detected. The results also show a decreasing content of the roentgen-amorphous phase.

The identified phases in the fresh solid body were composed of relatively semi-stable phases; primary-formed ettringite (PFE) in particular was able to change its composition because of the $\mathrm{pH}$ value of 7.5-8. Under these conditions, the unstable PFE decomposes and the roentgen-amorphous alumina-silicate might react to the newly formatted phases. This type of primary ettringite decomposition has been described previously [12].

The analysis of the eight-year-old outdoor sample in 2020 proved to have a major content of quartz $\left(\mathrm{SiO}_{2}\right)$; minor contents of calcite $\left(\mathrm{CaCO}_{3}\right)$, orthoclase $\left(\mathrm{KAlSi}_{3} \mathrm{O}_{8}\right)$ and albite $\left(\mathrm{Na}_{0.98} \mathrm{Ca}_{0.02}\right)\left(\mathrm{Al}_{1.02} \mathrm{Si}_{2.98} \mathrm{O}_{8}\right)$; traces of muscovite $\left(\left(\mathrm{KAl}_{2} \mathrm{Si}_{3} \mathrm{AlO}_{10}(\mathrm{OH})_{2}\right)\right.$; and a limited amount of the roentgen-amorphous phase. Bassanite was not detected.

Infrared analysis was also performed to verify changes in the phase composition of samples of various ages detected by $\mathrm{X}$-ray analysis.

The FTIR spectrum of the eight-year old outdoor sample (Figure 5) also showed the presence of carbonates (bands at 1437, 875 and $713 \mathrm{~cm}^{-1}$ ), quartz (bands at 799, 778 and $694 \mathrm{~cm}^{-1}$ ) and a set of alumina-silicates. The intensities of the bands related to carbonates and quartz were much higher than in the case of the spectrum of FFA. The bands of individual alumina-silicates were contained in one aggregated band centered at $1033 \mathrm{~cm}^{-1}$.

The deconvolution of the spectral region of $1250-900 \mathrm{~cm}^{-1}$ (Figure 6) revealed seven bands belonging to quartz, albite, orthoclase and muscovite that can be divided into two parts. The first of these $\left(1200-1050 \mathrm{~cm}^{-1}\right)$ is related to Si-O and Si-O-Si bonds, and the second $\left(1050-900 \mathrm{~cm}^{-1}\right)$ arises mainly from the second type of bridging (i.e., Si-O-Al stretching) [28]. The bands at 1165 and $1090 \mathrm{~cm}^{-1}$ in albite and 1090 and $1060 \mathrm{~cm}^{-1}$ in quartz belong to the Si-O-Si stretching vibrations, whereas $1125 \mathrm{~cm}^{-1}$ can be attributed to Si-O stretching vibrations in orthoclase [29]. The band at $1030 \mathrm{~cm}^{-1}$ belongs to $\mathrm{Si}-\mathrm{O}$ bonds in quartz as well as to $\mathrm{Si}-\mathrm{O}-\mathrm{Al}$ in albite [28] and the $\mathrm{Si}(\mathrm{Al})-\mathrm{O}$ stretching vibration in orthoclase [29]. Albite $\left(\mathrm{NaAlSi}_{3} \mathrm{O}_{8}\right)$ and orthoclase $\left(\mathrm{KAlSi}_{3} \mathrm{O}_{8}\right)$ are the extreme members of the plagioclase minerals, forming sodium and potassium feldspars, respectively. The bands attributed to Si-O-Al stretching vibrations in muscovite are evident at lower wavenumbers $(970$ and 
$\left.925 \mathrm{~cm}^{-1}\right)$. The region of $800-700 \mathrm{~cm}^{-1}$ originates from tetrahedral-tetrahedral ion vibrations and from a combination of $\mathrm{Si}(\mathrm{Al})-\mathrm{Al}-\mathrm{O}$ and $\mathrm{Si}-\mathrm{O}-\mathrm{Si}$ vibrational modes, and it is complex with contributions from high-frequency silica framework $\left(\mathrm{Si}_{2} \mathrm{O}\right)$ vibrations [30,31]. Therefore, the band around $778 \mathrm{~cm}^{-1} \mathrm{has} \mathrm{a}^{-1}$ higher intensity than the same band in the FFA spectrum. The bands in the region of $700-500 \mathrm{~cm}^{-1} \mathrm{are}^{-}$ attributed to $\mathrm{O}-\mathrm{Si}-\mathrm{O}$ and $\mathrm{O}-\mathrm{Al}-\mathrm{O}$ bending vibrations [31].

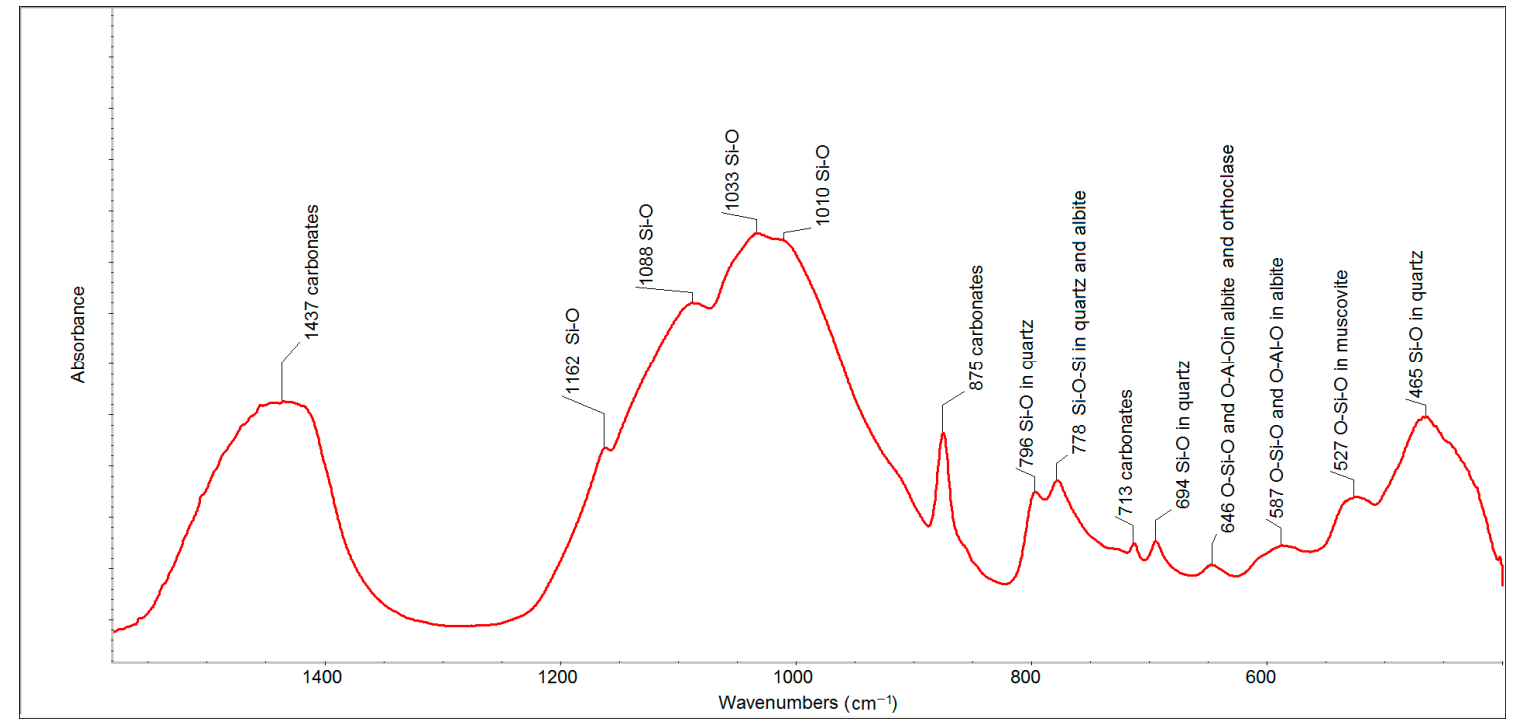

Figure 5. The FTIR spectrum of the outdoor sample (after eight years).

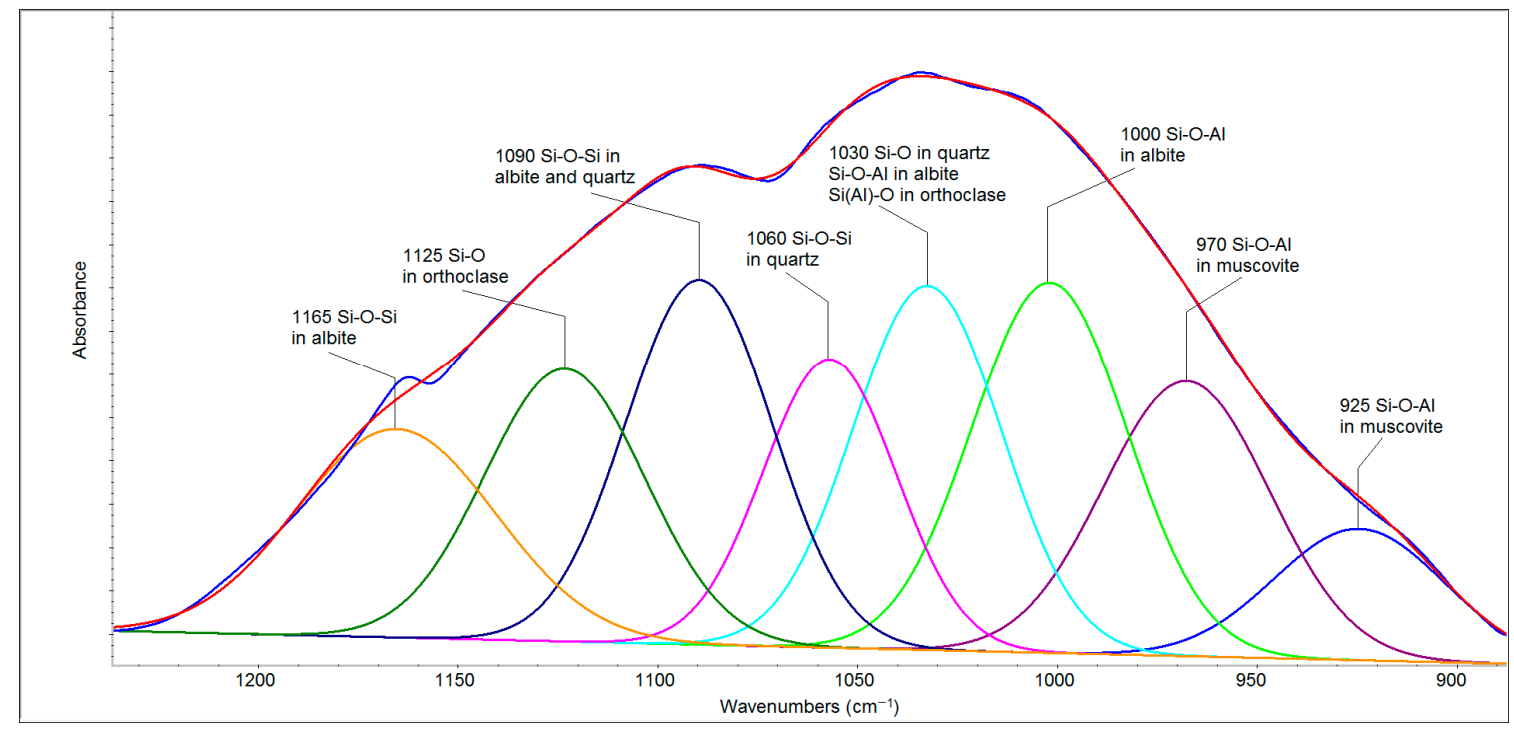

Figure 6. The deconvoluted spectral region of $1200-900 \mathrm{~cm}^{-1}$ of the outdoor sample (after eight years).

For the clarification of the disappearance of gypsum and aragonite in two-year-old samples, laboratory samples of solidified FFA were prepared (described in the Section 2.2 Sample Preparation above). These samples were placed in a plastic box and covered by a lid. The main attention was focused on the stability of the submerged sample. After several months, needle-like crystals began to appear on the surface of the body and flake shapes formed on the surface of the water. Figure 7 shows the state of the observed sample after its removal from the water. 


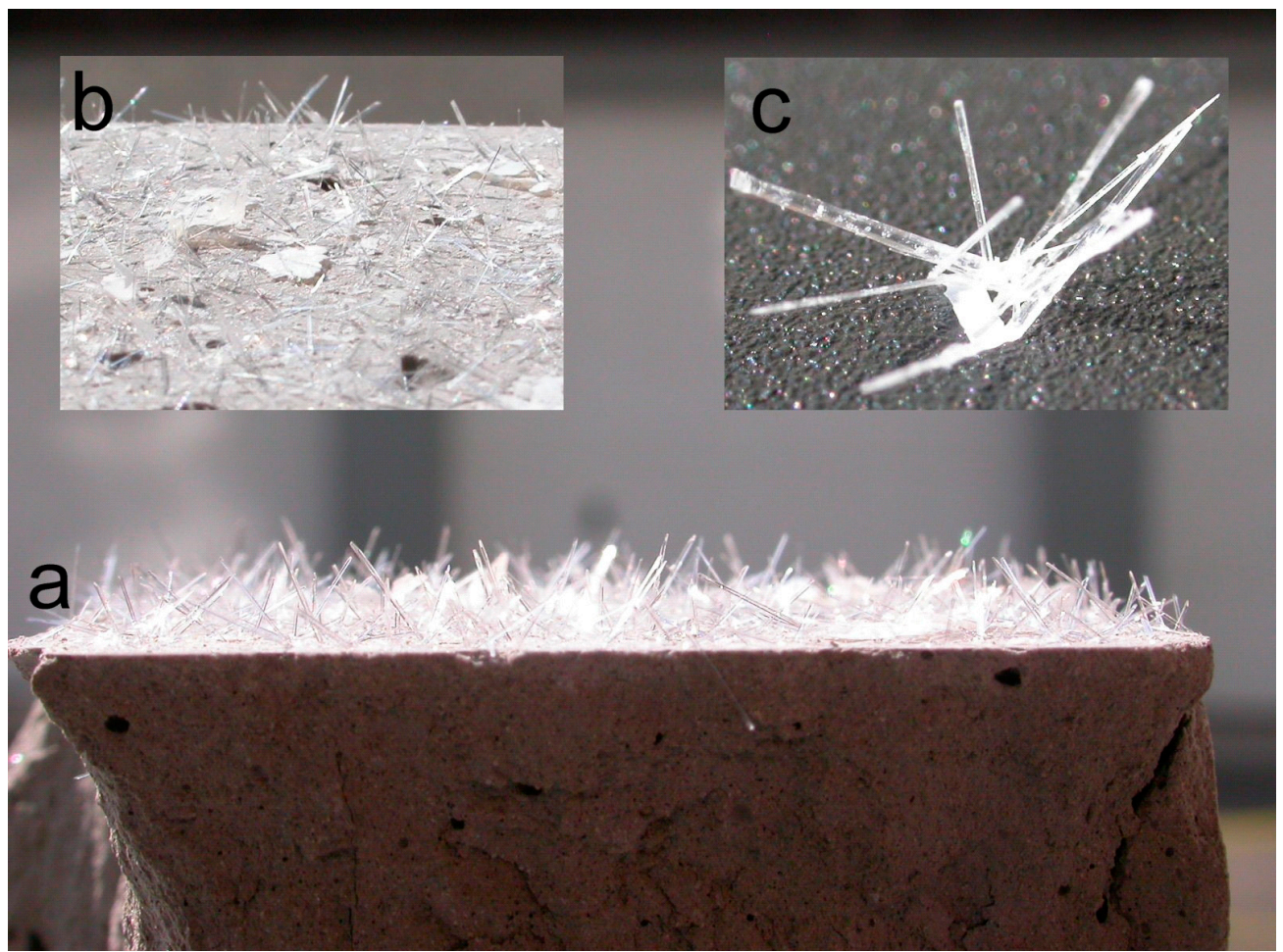

Figure 7. The surface of the solidified fluid-fly-ash sample: (a) a general view, (b) the surface with flake crystals, (c) the surface with needle-like crystals.

The top of the surface was densely covered by the needle-like formation of gypsum crystals. There were also calcite crystals of calcium carbonate on the surface in the form of flakes that had originally floated on the water surface.

This finding explains the disappearance of some phases (aragonite, bassanite and gypsum) and the decreasing contents of others (calcite) in the outdoor samples after two and eight years. The formation of both types of crystals means that these phases identified in FFA-based solids were in a soluble form and could, in contact with water, recrystallize without any visible damage of the compacted solidified body. The soluble forms of calcium sulfate have also been confirmed by several studies [32,33].

\section{Hypothesis}

The technology of half-dry pressing with limited water content does not permit ion migration in the bodies formed, and the solidification process mostly depends on the carbonation of lime. On the other hand, the presented amount of alumina-silicate is able to form the most stable system and highly resistant materials. Over time, by the effect of water as a medium transporting free ions, new phases are formed.

The submerged sample of solidified FFA had contained a highly soluble form of gypsum and calcite. These compounds were released from the solid, but in a form and quantities that did not damage the surface or structure of the whole body.

After the decomposition of ettringite in solids, calcium ions and sulfur oxide are likely to form bassanite and gypsum. However, as shown, these compounds crystallize on the surface, and the outdoor placement of solids results in their washing out. This has also been confirmed by the X-ray analysis of the samples after eight years in an outdoor environment, on which no crystalline substances containing sulfur were detected.

The main role in the presented hypothesis is played by the content of the roentgen-amorphous part of alumina-silicates, which, according to the chemical analyses of fluid fly ash, is more than $50 \mathrm{wt} . \%$ of all constituents. The mentioned alumina-silicates phases make clusters for future phase 
transformation. These clusters are waiting for the cations balancing the negative charge of the four-fold coordinated aluminum.

The natural state of all crystals is the most stable system of phases presenting the lowest energy potential. It may be supposed that the unbalanced part of alumina-silicate is affected by water, transporting alkali ions before finally forming a stable natural structure of feldspar.

The evidence supporting the hypothesis is as follows:

1. The analyses of fluid fly ash have proven the presence of the roentgen-amorphous phase in the form of alumina-silicates.

2. The NMR analysis of fluid fly ash has demonstrated that the aluminum ion predominantly appears in a four-fold coordination.

3. The XRD analyses of the outdoor samples presented in Table 3 detected:

- the decomposition of ettringite;

- the disappearance of sulfur-containing phases;

- the reduction of calcium-carbonate content;

- the formation of two new phases: orthoclase $\left(\mathrm{KAlSi}_{3} \mathrm{O}_{8}\right)$ and albite $\left(\mathrm{Na}_{0.98} \mathrm{Ca}_{0.02}\right)\left(\mathrm{Al}_{1.02} \mathrm{Si}_{2.98} \mathrm{O}_{8}\right)$.

4. Infrared analyses confirmed the formation of feldspars.

5. The laboratory experiment with the submerged solid based on FFA demonstrated that carbonates and sulfates occur in a soluble form and can recrystallize on a surface without any visible damage to the compacted solidified body.

6. The stability of the sample was confirmed by its eight-year exposure to the outdoor environment without visible signs of any degradation.

Based on the results, the hypothesis presented and the evidence supporting it, a scheme describing phase transformations in fly-ash-based solids has been proposed (Figure 8).

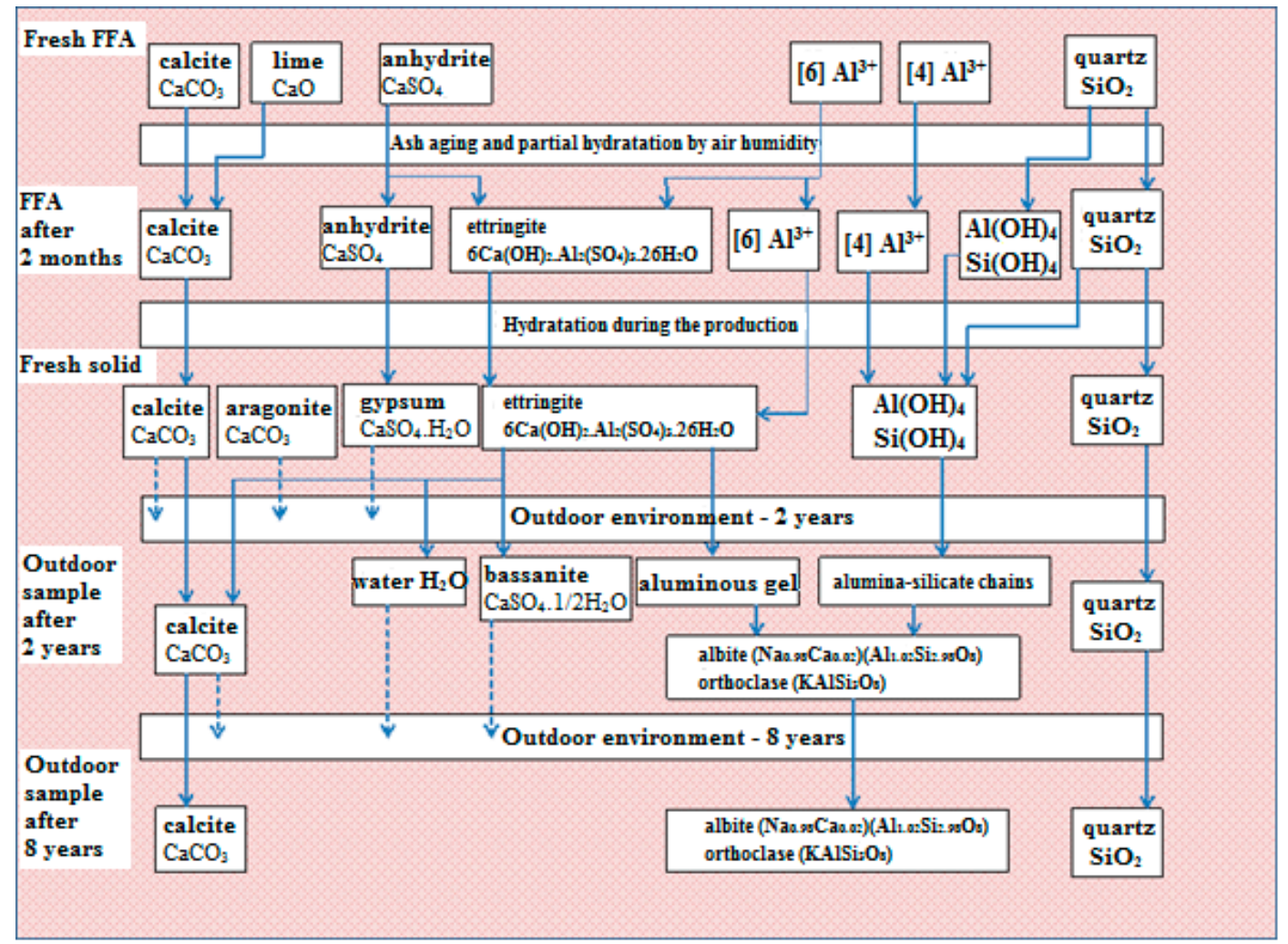

Figure 8. A scheme of phase transformations in fly-ash-based solids. 


\section{Conclusions}

It can be concluded that the roentgen-amorphous phase of fluid fly ash contains alumina-silicate in active forms. Thermally treated clay residues in coal ash form separated chained tetrahedrons. The negative charge of the aluminum ion in five-/four-fold coordination to oxygen is finally balanced by the positive charge of alkali. The small and separated chained structures are spread in calcareous surroundings in the form of alumina-silicate clusters. These clusters are not connected to the significant $3 \mathrm{D}$ netting corresponding to geopolymers, but have the potential to create new phases.

The presented hypothesis supposes that water as a moving agent transports highly movable alkali ions and allows the transformation of roentgen-amorphous phases into the identified crystals of feldspathoids, which finally create feldspar. These gradual phase transformations at normal temperatures and pressures have been observed in long-term experiments and corroborated by the XRD method.

Supplementary Materials: The following are available online at http://www.mdpi.com/2075-163X/10/9/804/s1, Figure S1: Fresh FFA, Figure S2: FFA after 2 months, Figure S3: Fresh solid, Figure S4: Outdoor sample after 2 years, Figure S5: Outdoor sample after 8 years.

Author Contributions: Conceptualization, I.P. and T.H.; methodology, I.P. and M.Š.; formal analysis, I.P. and M.Š.; investigation, I.P. and T.H.; data curation, I.P., T.H. and M.N.; writing — original draft preparation, I.P. and T.H.; writing-review and editing, I.P., T.H., M.Š. and M.N.; supervision, I.P. All authors have read and agreed to the published version of the manuscript.

Funding: This research received no external funding. This work was carried out thanks to the support of the long-term project for the conceptual development of the research organization No. 67985891.

Acknowledgments: The authors would like to thank Adam Lučaník for technical support and transport of the samples, as well as the reviewers and editor for the manuscript revision.

Conflicts of Interest: The authors declare no conflict of interest.

\section{References}

1. Farret, F.A.; Simoes, M.G. Integration Alternative Sources Energy; John Wiley \& Sons: Hoboken, NJ, USA, 2006.

2. Kalogirou, S.A. Solar Energy Engineering: Processes Systems, 2nd ed.; Elsevier: San Diego, CA, USA, 2014; pp. $1-47$.

3. BP. Statistical Review of World Energy, 69th ed. 2020. Available online: https://www.bp.com/content/dam/ bp/business-sites/en/global/corporate/pdfs/energy-economics/statistical-review/bp-stats-review-2020-fullreport.pdf (accessed on 27 July 2020).

4. Shahzad Baig, K.; Yousaf, M. Coal Fired Power Plants: Emission Problems and Controlling Techniques. J. Earth Sci. Clim. Chang. 2017, 8, 2. [CrossRef]

5. Zhao, Z.Y.; Cao, F.; Fan, M.Y.; Zhang, W.Q.; Zhai, X.Y.; Wang, Q.; Zhang, Y.L. Coal and Biomass Burning as Major Emissions of NOX in Northeast China: Implication from Dual Isotopes Analysis of Fine Nitrate Aerosols. Atmos. Environ. 2020, 117762. [CrossRef]

6. Ahmaruzzaman, M. A Review on the Utilization of Fly Ash. Prog. Energy Combust. Sci. 2010, 36, 327-363. [CrossRef]

7. Vassilev, S.V. Phase Mineralogy Studies of Solid Waste Products from Coal Burning at Some Bulgarian Thermoelectric Power Plants. Fuel 1992, 71, 625-633. [CrossRef]

8. Córdoba, P. Status of Flue Gas Desulphurisation (FGD) Systems from Coal-fired Power Plants: Overview of the Physic-chemical Control Processes of Wet Limestone FGDs. Fuel 2015, 144, 274-286. [CrossRef]

9. Rajabipour, F.; Aci, F.; Zahedi, M.; Kaladharan, G. Evaluating the Performance and Feasibility of Using Recovered Fly Ash and Fluidized Bed Combustion (FBC) Fly Ash as Concrete Pozzolan; Technical Report for Pennsylvania Coal Ash Research Group (PCARG): Pennsylvania, PA, USA, March 2020.

10. Abanades, J.C.; Anthony, E.J.; Wang, J.; Oakey, J.E. Fluidized Bed Combustion Systems Integrating $\mathrm{CO}_{2}$ Capture with CaO. Environ. Sci. Technol. 2005, 39, 2861-2866. [CrossRef]

11. Minchener, A.J. Fluidized Bed Combustion Systems for Power Generation and Other Industrial Applications. Proc. Inst. Mech. Eng. Part A J. Power Energy 2003, 217, 9-18. [CrossRef] 
12. Hanzlíček, T.; Perná, I. The Alumina-silicates in Stabilization Processes in Fluidized-bed Ashes. Ceram. Silik 2011, 55, 94-99.

13. Sulovsky, P. Mineralogy and Chemistry of Conventional and Fluidised Bed Coal Ashes. Bull. Czech Geol. Surv. 2002, 77, 1-11, ISSN 1210-3527.

14. Strigáč, J.; Števulová, N.; Mikušinec, J.; Sobolev, K. The Fungistatic Properties and Potential Application of By-product Fly Ash from Fluidized Bed Combustion. Constr. Build. Mater. 2018, 159, 351-360. [CrossRef]

15. Perná, I.; Šupová, M.; Hanzlíček, T. Gehlenite and Anorthite Formation from Fluid Fly Ash. J. Mol. Struct. 2018, 1157, 476-481. [CrossRef]

16. Koukouzas, N.; Hämäläinen, J.; Papanikolaou, D.; Tourunen, A.; Jäntti, T. Mineralogical and Elemental Composition of Fly Ash from Pilot Scale Fluidised Bed Combustion of Lignite, Bituminous Coal, Wood Chips and Their Blends. Fuel 2007, 86, 2186-2193. [CrossRef]

17. Manz, O.E. Coal Fly Ash: A Retrospective and Future Look. Fuel 1999, 78, 133-136. [CrossRef]

18. Davidovits, J. Geopolymer: Chemistry E Application, 4th ed.; Geopolymer Institute: Saint-Quentin, France, 2008.

19. Provis, J.L. Alkali-activated Materials. Cem. Concr. Res. 2018, 114, 40-48. [CrossRef]

20. Temuujin, J.; van Riessen, A.; MacKenzie, K.J.D. Preparation and Characterisation of Fly Ash Based Geopolymer Mortars. Constr. Build. Mater. 2010, 24, 1906-1910. [CrossRef]

21. Zhuang, X.Y.; Chen, L.; Komarneni, S.; Zhou, C.H.; Tong, D.S.; Yang, H.M.; Yu, H.W.; Wang, H. Fly Ash-based Geopolymer: Clean Production, Properties and Applications. J. Clean. Prod. 2016, 125, 253-267. [CrossRef]

22. Škvára, F.; Šulc, R.; Snop, R.; Peterová, A.; Šídlová, M. Hydraulic Clinkerless Binder on the Fluid Sulfocalcic Fly Ash Basis. Cem. Concr. Compos. 2018, 93, 118-126. [CrossRef]

23. Kuenzel, C.; Ranjbar, N. Dissolution Mechanism of Fly Ash to Quantify the Reactive Aluminosilicates in Geopolymerisation. Resour. Conserv. Recycl. 2019, 150, 104421. [CrossRef]

24. Váchal, T.; Šulc, R.; Janků, T.; Svoboda, P. Influence of Milling on Some Chemical Properties and Reactivity of CFBC Fly Ash. Key Eng. Mater. 2018, 760, 73-80. [CrossRef]

25. Fu, Q.; Lu, P.; Konishi, H.; Dilmore, R.; Xu, H.; Seyfried, W.E., Jr.; Zhu, C. Coupled Alkali-feldspar Dissolution and Secondary Mineral Precipitation in Batch Systems: 1. New Experiments at $200 \mathrm{C}$ and 300 Bars. Chem. Geol. 2009, 258, 125-135. [CrossRef]

26. Hanzlíček, T.; Perná, I.; Steinerová, M.; Straka, P. Pozzolanic Properties of Fluidized Bed Ashes. In Alkali Activated Materials—Research, Production and Utilization; Action, M., Ed.; Agentura Action M: Prague, Czech Republic, 2007; pp. 270-283.

27. Fernández-Carrasco, L.; Torrens-Martín, D.; Morales, L.M.; Martínez-Ramírez, S. Infrared spectroscopy in the analysis of building and construction materials. In Infrared Spectroscopy-Materials Science, Engineering and Technology, 1st ed.; Theophanides, T., Smiljanic, T., Eds.; IntechOpen: Rijeka, Croatia, 2012; pp. 369-382.

28. Jovanovski, G.; Makreski, P. Minerals from Macedonia. XXX. Complementary Use of Vibrational Spectroscopy and X-ray Powder Diffraction for Spectra-structural Study of Some Cyclo-, Phyllo-and Tectosilicate Minerals. A Review. Maced. J. Chem. Chem. Eng. 2016, 35, 125-155. [CrossRef]

29. Theodosoglou, E.; Koroneos, A.; Soldatos, T.; Zorba, T.; Paraskevopoulos, K.M. Comparative Fourier Transform Infrared and X-ray Powder Diffraction Analysis of Naturally Occurred K-feldspars. Bull. Geol. Soc. Greece 2010, 43, 2752-2761. [CrossRef]

30. Handke, M.; Mozgawa, W. Vibrational Spectroscopy of the Amorphous Silicates. Vib. Spectrosc. 1993, 5, 75-84. [CrossRef]

31. Iishi, K.; Tomisaka, T.; Kato, T.; Umegaki, Y. Isomorphous Substitution and Infrared and Far Infrared Spectra of Feldspar Group. Neuse Jahrb. Mineral. 1971, 115, 98-119.

32. Bezou, C.; Nonat, A.; Mutin, J.C.; Christensen, A.N.; Lehmann, M.S. Investigation of the Crystal Structure of $\gamma-\mathrm{CaSO}_{4}, \mathrm{CaSO}_{4} \cdot 0.5 \mathrm{H}_{2} \mathrm{O}$, and $\mathrm{CaSO}_{4} \cdot 0.6 \mathrm{H}_{2} \mathrm{O}$ by Powder Diffraction Methods. J. Solid State Chem. 1995, 117, 165-176. [CrossRef]

33. Lisitsin-Shmulevsky, M.; Li, X.; Hasson, D.; Shemer, H.; Semiat, R. Solubility Limits of $\mathrm{CaSO}_{4}$ Polymorphs in Seawater Solutions. Desalin 2020, 475, 114200. [CrossRef] 